\title{
Assessment of Oral Hygiene Status by Using Disclosing Agents to Schoolchildren from Rural Areas
}

\author{
BIANCA IOANA TODOR, LUMINITA LIGIA VAIDA*, ABEL EMANUEL MOCA, BIANCA NEGRUTIU, TEODORA STEFANESCU, \\ ALEXANDRA IOANA LUCAN, IOANA SCROBOTA \\ University of Oradea, Faculty of Medicine and Pharmacy, Department of Dentistry, $1^{\text {st }}$ Universitatii Str., 410087, Oradea, Romania
}

\begin{abstract}
Poor oral hygiene, in terms of gingival bleeding and increasing accumulation of plaque and calculus with increasing age, have been reported among school-aged children, in both developed-and developing countries, causing unsatisfactory oral health among children. The aim of this study was to determine oral hygiene status by calculating Oral Hygiene Index -Simplified (OHI-S), using disclosing agents, and to examine whether socio-economic and behavioral correlates of oral hygiene status, in school children from rural areas, N-W Romania. For the highlighting of the bacterial plaque were used two tone dental plaque disclosing agent, which contains Erythrosine and Brilliant Blue FCF. The OHI-S index is divided according to its values in several categories as follows: very good hygiene $=\mathrm{OHI}-\mathrm{S}$ Index between $\mathrm{O}$ and 1; good hygiene $=\mathrm{OHI}-$ SIndex between 1.1 and 2; unsatisfactory hygiene $=\mathrm{OHI}$-S Index between 2.1 and 3; poor hygiene = Index $\mathrm{OHI}-\mathrm{S}$ between 3.1 and 6. The average value of the $\mathrm{OHI}-\mathrm{S}$ index in children in rural areas of $\mathrm{N}-\mathrm{W}$ Romania was 1.78, a higher value than most of the values identified in the bibliographical references. Using disclosing agents may improve oral health status in schoolchildren, by increasing the awareness of their personal oral hygiene condition.
\end{abstract}

Keywords: oral hygiene, disclosing agents, OHI-S, socio-economic status

Oral disease is still a major public health problem in high income countries and the burden of oral disease is growing in many low- and middle-income countries. Oral diseases can lead to irreversible damage and unnecessary pain, and further result in dental anxiety, general health problems, depression, low self-esteem, lost school time and poor quality of life [1-3].

Oral health may be influenced by socio-cultural factors, inadequate oral habits, low level of hygiene knowledge, and lacking infrastructure that significantly affects screening of oral diseases, especially in rural areas [4].

Socio-economic status has a profound effect on healthand health behaviors. The lower the material standard of living as measured by income, social class and social network and support, the worse the level of oral health, whatever the measures used, being they clinical or selfreported oral health indicators [5].

Poor oral hygiene, in terms of gingival bleeding and increasing accumulation of plaque and calculus with increasing age, have been reported among school-aged children, in both developed- and developing countries, causing unsatisfactory oral health among children. Their oral health is therefore a significant public health concern; reducing the burden of oral diseases in schoolchildren is a global goal of the World Health Organization [6-9].

Bacterial plaque can be accurately localized with special disclosing agents containing dyes or other coloring agents, namely iodine, gentian violet, erythrosine, basic fuchsine, fast green, food dyes, fluorescein, and two-tone disclosing agents in the form of tablets, solutions, wafers, or mouth rinses [10].

Historically there were used several disclosing solutions as could be seen within table 1 listed below.

Disclosing agents are used in various aspects: to evaluate the effectiveness of oral hygiene maintenance; for the preparation of plaque indices; to personalize the patient instruction and motivation; for self-evaluation by the patient; for plaque control in special in children; in research studies with regard to the effectiveness of plaque control devices like toothbrushes, dentifrices; to evaluate the amount of removal of biofilm during and after respective periodontal surgeries [12-16].

Information on oral hygiene and periodontal health of children and adolescents, and oral health attitudes and behavior, especially in rural areas, is lacking, where mass oral health awareness has been reported to be low [1718].

The aim of this study was to determine oral hygiene status by calculating Oral Hygiene Index -Simplified $(\mathrm{OHI}-$ S), using disclosing agents, and to examine whether socioeconomic and behavioral correlates of oral hygiene status, in school children from rural areas, N-W Romania.

\begin{tabular}{|l|l|l|}
\hline SCIENTISTS & Year & \multicolumn{1}{c|}{ Solution used } \\
\hline SKINNER & 1914 & PIONEER IN USING DISCLOSING AGENT (USED IODINE) \\
\hline BERWICK & 1920 & COMBINATION OF BRILLIANT GREEN AND CRYSTAL VIOLET \\
\hline EASLICK & 1935 & BISMARK BROWN \\
\hline RAYBIN & 1943 & GENTIAN VIOLET \\
\hline AMIM & 1963 & F.D. \& C. RED \#3 (ERYTHROSIN) DYE \\
\hline LANG & 1972 & PLAKLITE@ (FLUORESCENT DISCLOSING AGENT) \\
\hline BLOCK & 1972 & TWO TONE DYE (F. D. \& C. GREEN \#3 AND F. D. \& C. RED \#3) \\
\hline
\end{tabular}

Table 1

HISTORICAL MILESTONES OF DISCLOSING SOLUTIONS [11] 


\section{Experimental part}

The study was conducted in the period 2016-2017 and is a descriptive transversal study. The study area comprises four rural localities, in the Apuseni Mountains, N-W Romania, with low living standards, isolated from the point of view of access to pediatric dentistry services.

The studied group consisted of 960 children from the studied area ( 518 boys and 442 girls), aged between 7 and 14 years, children in the mixed dentition period, randomly selected from the schools belonging to the study area.

By simple random design, using statistical formulas for sample size determination, for a total population of 2000 children, at a confidence interval of $95 \%$, and an accuracy interval of 3\%, resulting sample size was 714 children [19].

Considering the above we concluded that the group of 960 subjects is a significant sample from the perspective of our research

Recruited children have been examined in school doctors cabinets or in a classroom provided for consultations, as appropriate. The consultations were conducted according to the WHO recommendations [20].

We used several exclusions criteria, such as:

-Children subjects with deciduous dentition;

-Children subjects following orthodontic treatment;

-Children subjects for whom we could not obtain the study informed permission.

We have not included within the study children with orthodontic treatment because both the removable appliances ( made of thermoplastic and thermo setresins) as well as fixed appliance and auxiliary elements (hyrax, distaliser, myofunctional trainer) favorizes additional retention of bacterial plaque. Also, the component elements of orthodontic appliances on the vestibular surface of the teeth make it impossible to determine the $\mathrm{OHI}-\mathrm{S}$ Index [21-23].

The study was conducted in accordance to the World Medical Association (WMA) Declaration of Helsinki - Ethical Principles for Medical Research Involving Human Subjects approved by the Ethics Committee of the University of Oradea, Romania. All subjects taken part in the study were having their parents' written consent.

The dental hygiene status of each child included in the study sample was investigated by calculating the $\mathrm{OHI}-\mathrm{S}$ index. 6 suitable surfaces of 6 teeth, 2 teeth from the anterior region and 4 teeth from the posterior region have been selected. In the front region were selected incisors 1.1 and 3.1, and in the absence of these were counted the homogeneous tooth on the other side of the median line. In the posterior region, the 6-year molar, respectively 1.6, 2.6, 3.6 and 4.6, were selected, and in the absence of them was considered the next erupted, 1.7 respectively, and in the case of children under 12 years where 1.7 was not present in the dental formula, the last premolar present on the arch was taken into account. In the case of the previous mentioned elected teeth, the vestibular surfaces of upper posterior teeth were analyzed, while for the lower posterior teeth, the lingual surfaces were also analyzed. With the help of a probe were investigated areas chosen both in terms of the presence of soft deposits, resulting in the DI$S$ index (Debrids) and the presence of tartar, resulting in the CI-S index (Calculus). The values of the DI-S and CI-S indices may vary between 0 and 3 and their summation gives the $\mathrm{OHI}-\mathrm{S}$ index, the value of which can fall betw een 0 and 6 [24].

For the highlighting of the bacterial plaque were used two tone dental plaque disclosing agent, which contains Erythrosine and Brilliant Blue FCF.
Erythrosine, also known as Red No. 3, E127 is an organoiodine compound, specifically a derivative of fluorone. It is a pink dye which is primarily used for food coloring. The maximum daily dosage is $0.1 \mathrm{mg} / \mathrm{kg}$ body. It is the disodium salt of 2,4,5,7-tetraiodofluorescein. IUPAC name is 2-(6-Hydroxy-2,4,5,7-tetraiodo-3-oxo-xanthen-9yl) benzoic acid.

Brilliant Blue FCF is a synthetic organic compound primarily used as a blue colorant for processed foods, medications, dietary supplements, and cosmetics. It is classified as a triarylmethane dye and is known under various names, such as FD\&C Blue No. 1 or Acid Blue9. IUPAC name is disodium; 2-[[4-[ethyl-[( 3-sulfonatophenyl) methyl]amino]phenyl]-[4-[ ethyl-[(3-sulfonatophenyl) methyl] azaniumylidene]cyclohexa-2,5-dien-1-ylidene] methyl] benzenesulfonat [24].

Children were asked to chew the tablets with disclosing agent and then to rinse. Red colored stains on the teeth indicate areas where plaque has been recently installed, and blue colored stains indicate areas where plaque was installed at least 2-3 days ago (fig. 1). For self-examination, a sterile mirror was used. Schoolchildren could visually notice plaque on tooth surfaces by themselves, to make them aware of their own dental hygiene and as a feedback mechanism for improving their brushing technique.

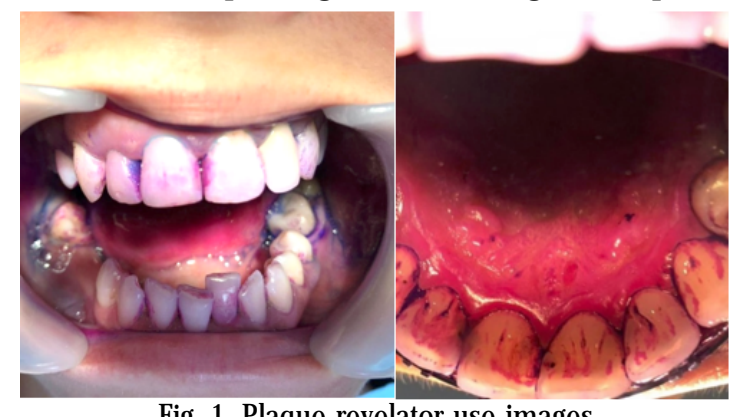

Fig. 1. Plaque revelator use images

The batch was divided into subgroups according to the following socio-demographic factors: age, gender, ethnicity, socio-economic status of the child's family of origin. Socio-economic status was considered the level of income of parents and parents' education.

The distribution of the batch according to the state of dental hygiene resulted from the values of the OHI-S index, as well as the correlation between the hygiene status of children in the study group and the socio-demographic factors, were analyzed in order to provide information to develop tailored prophylaxis programs.

Clinical statistical studies were conducted following the clinical diagnostic variables applied on the database. The analysis of the data and the interpretation of the results was carried out using statistical analysis. The program used was MedCalc, version 9.4.2.0. The lot's subgroups were quantified as categorical variables (gender, environment, ethnicity) or continuing variables (OHIS). The results of the statistical tests have been represented by the probability of the null hypothesis revealed by the value of the coefficient $P$. Its value below 0.05 proves a statistically significant difference between the parameters studied. Categorical variables with values above 20 have been analyzed with the chi square test.

The continuous variables have been modeled through a statistical summary and evaluated their distribution and normal framing with the help of Kolmogorov Smirnov test. In those with distribution that rejects normality, the KruskalWallis nano-parametric test has been applied, and a posthoc analysis was applied to detect differences between subgroups. 


\section{Results and discussions}

Female gender accounted for $46.04 \%$ of the study group, and the male gender accounted for $53.96 \%$ (table 2).

Table 2

DISTRIBUTION OF STUDY GROUP BY GENDER

\begin{tabular}{|c|c|c|}
\hline Gender & Frequency & $\%$ \\
\hline Female & 442 & $46.04 \%$ \\
\hline Male & 518 & $53.96 \%$ \\
\hline
\end{tabular}

The age category 7-9 years predominates, representing $45.10 \%$ of the study group, the $10-12$-year-olds are $40.9 \%$ of the batch, and those over 12 years $14 \%$ of the batch (table 3).

Table 3

GROUP DISTRIBUTION BY AGE

\begin{tabular}{|c|c|c|}
\hline Age category & Frequency & $\%$ \\
\hline 7-9 year-old & 393 & $40.90 \%$ \\
\hline $10-12$ year-old & 433 & $45.10 \%$ \\
\hline$>12$ year-old & 134 & $14.00 \%$ \\
\hline Total & 960 & $100.00 \%$ \\
\hline
\end{tabular}

The ethnical composition of the batch consists of Romanians and Roma children, Romanians dominating the batch (table 4).

Table 4

DISTRIBUTION OF STUDY GROUP BY ETHNICITY

\begin{tabular}{|c|c|c|}
\hline Ethnicity & Frequency & $\%$ \\
\hline Majority, Romanian & 836 & $87.08 \%$ \\
\hline Minority, Roma & 124 & $12.02 \%$ \\
\hline
\end{tabular}

Within the study group, an average level of parental education is predominant (68.4\%), whilst parents with a higher level of education represent $15.5 \%$ (table 5 ).

Table 5

DISTRIBUTION OF STUDY GROUP BY PARENTAL LEVEL OF EDUCATION

\begin{tabular}{|c|c|c|}
\hline Level of education & Frequency & $\%$ \\
\hline 4 Grades & 42 & $4.40 \%$ \\
\hline $4-8$ Grades & 112 & $11.70 \%$ \\
\hline $8-12$ Grades & 657 & $68.40 \%$ \\
\hline$>12$ Grades & 149 & $15.50 \%$ \\
\hline Total & 960 & $100.00 \%$ \\
\hline
\end{tabular}

The children family income level in the study group is low, dominating the income category between RON 500900 (table 6).

Table 6

DISTRIBUTION OF STUDY GROUP BY FAMILY INCOME LEVEL

\begin{tabular}{|c|c|c|}
\hline $\begin{array}{c}\text { Level of income } \\
\text { (measured in RON) }\end{array}$ & Frequency & $\%$ \\
\hline$<500$ & 101 & $10.5 \%$ \\
\hline $500-900$ & 330 & $34.4 \%$ \\
\hline $901-1600$ & 324 & $33.7 \%$ \\
\hline PESTE 1600 & 205 & $21.4 \%$ \\
\hline Total & 960 & $100.0 \%$ \\
\hline
\end{tabular}

Table 7

STATISTICAL SUMMARY FOR OHIS-SIMPLIFIED ORAL HYGIENE INDEX

\begin{tabular}{|c|c|}
\hline Study group size & 960 \\
\hline $\begin{array}{c}\text { The smallest OHI-S } \\
\text { value }\end{array}$ & 0.3300 \\
\hline The largest OHI-S value & 4.2200 \\
\hline Geometric mean & 1.6211 \\
\hline $\begin{array}{c}95 \% \text { mean confidence } \\
\text { pace }\end{array}$ & 1.5740 to 1.6696 \\
\hline $\begin{array}{c}\text { Kolmogorov- } \\
\text { Smimov test for normal } \\
\text { distribution }\end{array}$ & $\begin{array}{c}\text { Rejects normality } \\
(\mathrm{P}=0.0001)\end{array}$ \\
\hline
\end{tabular}

The distribution of OHI-S subjected to the Kolmogorov Smirnov test is heterogeneous, rejecting normality (see table 7).

The $\mathrm{OHI}-\mathrm{S}$ index is divided according to its values in several categories as follows: very good hygiene $=\mathrm{OHI}-\mathrm{S}$ Index between 0 and 1 ; good hygiene $=\mathrm{OHI}-\mathrm{S}$ Index between 1.1 and 2; unsatisfactory hygiene $=\mathrm{OHI}-\mathrm{S}$ Index between 2.1 and 3; poor hygiene = Index OHI-S between 3.1 and 6 (fig. 2).

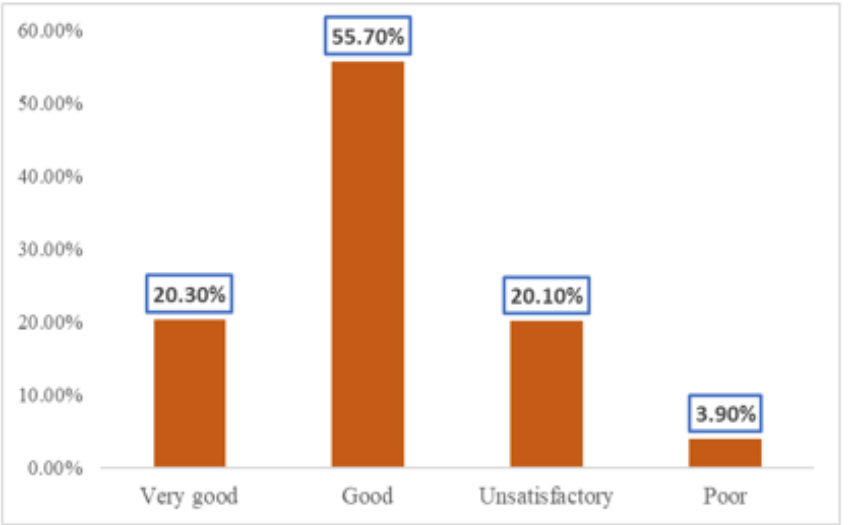

Fig. 2. OHI-S Index general distribution

There is statistically significant difference between the values of OHIS in Roma children and the majority Romanian subjects. The didactic division of OHIS into four categories, in order to be able to better visualize the distribution of the study group (table 8), allowed the distribution of Roma and Romanians to be highlighted according to the hygiene category. Thus, the percentage of the Romanians decreased with the increase of the OHIS index from 98.9 to $96.2 \%$, then $64.7 \%$, then to $8.8 \%$. The percentage of Roma increased with the increase of the OHI-S index from 1.1\% to $3.8 \%$ then $35.3 \%$ and $91.2 \%$. The average value for the $\mathrm{OHI}$-S index in Romanian subjects is significantly lower than that of Roma subjects (fig. 3).

There are no differences between age groups from the point of view of the OHI-S index (table 9).

In Romanian subjects, oral hygiene improves with age growth, as the OHIS index decreases with increasing age. In Roma subjects there are no statistically significant differences between age groups (fig. 4).

There are statistically significant differences between $\mathrm{OHI}-\mathrm{S}$ distribution within the different income categories. The examination by category shows the existence of $\mathrm{OHI}$ $\mathrm{S}$ statistically relevant differences between all categories

\begin{tabular}{|c|c|c|c|c|c|}
\hline Ethnicity & Very good & Good & Unsatisfactory & Poor & \\
\hline Majority & 193 & 515 & 125 & 3 & $836(87.10 \%)$ \\
\hline Roma & 2 & 20 & 68 & 34 & $124(12.90 \%)$ \\
\hline Total & $195(20.3 \%)$ & $535(55.7 \%)$ & $193(20.10 \%)$ & $37(3.90 \%)$ & 960 \\
\hline \multicolumn{3}{|c|}{ Chi square test results } & \multicolumn{3}{|c|}{355.195} \\
\hline \multicolumn{2}{|c|}{ Statistical significance } & \multicolumn{4}{c|}{ P 20001} \\
\hline
\end{tabular}

Table 8

DISTRIBUTION OF OHI-S INDEX BY ETHNICITY 


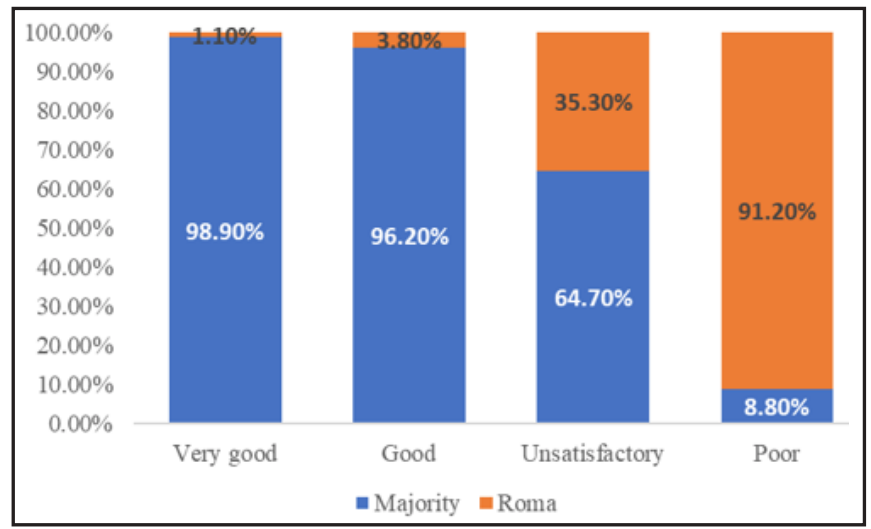

Fig. 3. Distribution of OHI-S categories by ethnicity

Table 9

STATISTICAL SIGNIFICANCE OF OHI-S DISTRIBUTION BY ETHNICITY

\begin{tabular}{|c|c|c|}
\hline Age category & Frecuency & Mean of ranks \\
\hline (1) 7-9-year-old & 393 & 486.13 \\
\hline (2) 10-12-year-old & 433 & 464.09 \\
\hline (3) >12-year-old & 134 & 517.01 \\
\hline Statistical significance & \multicolumn{2}{|c|}{$\mathrm{P}=0.132221$} \\
\hline
\end{tabular}

${ }^{*}$ Test Kruskal Wallis

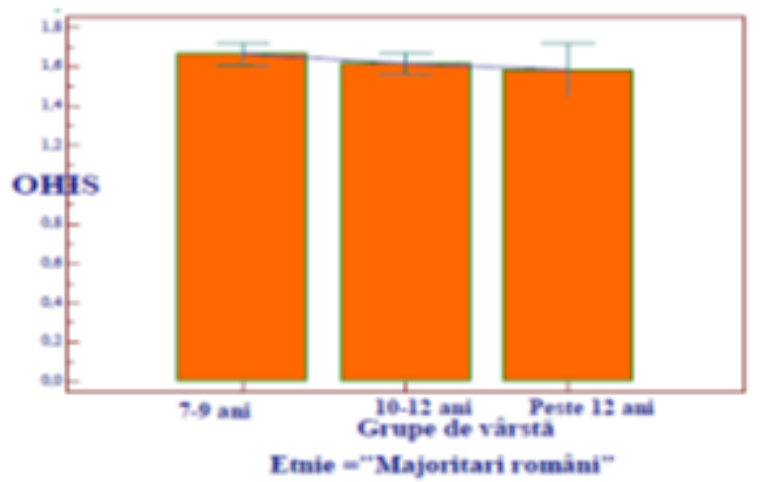

$\bullet P=0,013718$

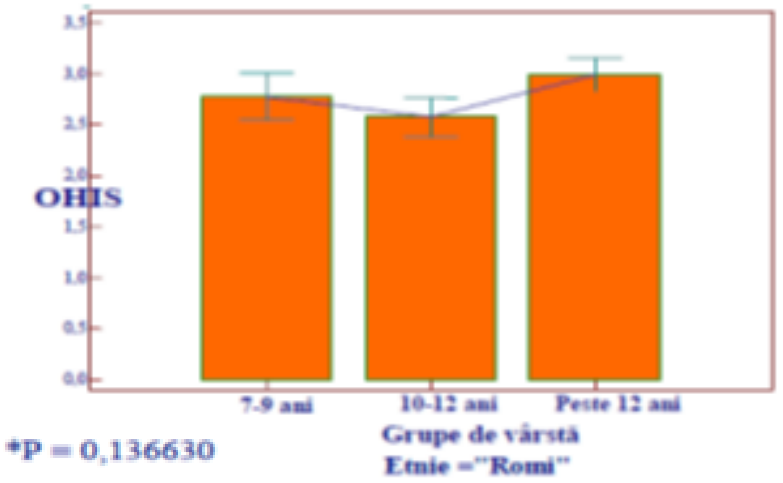

Fig. 4. Statistical significance of OHI-S distribution by ethnicity and age category
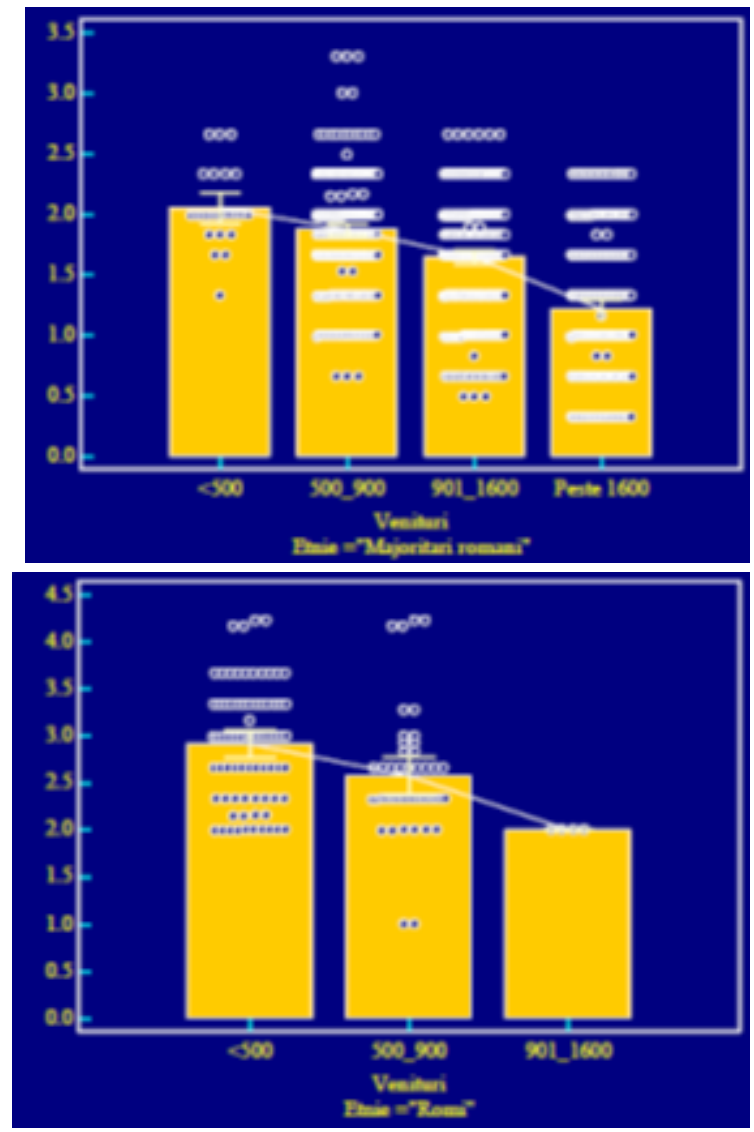

Fig. 5. OHI-S distribution by income and ethnicity

of income (table 10). The OHIS index is higher in each Roma income category compared to Romanians and the trend is to decrease the OHIS index with increasing income to both ethnicities (fig. 5).

The OHIS changes significantly according to the level of education, all subgroups differ between them (table 11). $\mathrm{OHI}-\mathrm{S}$ decreases with the increasing level of education in both Romanians and Roma. In each class of income Romanian subjects were measured lower OHI-S values than the Roma (fig. 6).

The average value of the OHIS index in the batch was 1.78. This value is higher than in other studies describing OHIS index values for the Middle East and South Asia, 0.90/ 0.84. [25] In Tibet another study obtained OHI-S values of 0.69 in children [26]. A French study of psychiatric patients obtained values similar to those in our study (1.7) [27].

In India was determined a higher value of OHI-S, amongst governmental school children, of 2.9 [28-29].

In Eastern Europe, a pilot project to improve oral health of orphans in Constanta, revealed OHI-S values between $1.4-0.8$. Also, a research in Kosovo showed an average value of 1.43 [30-31].

\begin{tabular}{|l|c|c|c|}
\hline Income level (RON) & Frequency & Mean of ranks & Difrent $(\mathrm{P}<0.05)$ of , $\mathbf{n}^{\text {" factor }}$ \\
\hline (1) $<500$ & 101 & 797.27 & $(2)(3)(4)$ \\
\hline (2) $500-900$ & 330 & 568.31 & $(1)(3)(4)$ \\
\hline (3) $901-1600$ & 324 & 425.85 & $(1)(2)(4)$ \\
\hline \multicolumn{2}{|c|}{ Statistical significance* } & 269.45 & $(1)(2)(3)$ \\
\hline \multicolumn{2}{|c|}{} & P 00.000001 \\
\hline
\end{tabular}

Table 10

STATISTICAL SIGNIFICANCE OF OHI-S DISTRIBUTION BY FAMILY LEVEL OF INCOME

"test Kruskal Wallis

\begin{tabular}{|c|c|c|c|}
\hline Education category & Frequency & Mean of ranks & Difrent $(\mathbf{P}<\mathbf{0 . 0 5}$ of, $\mathbf{n}$ " factor \\
\hline (1) 4 Grades & 42 & 879,26 & $(2)(3)(4)$ \\
\hline (2) 4-8 Grades & 112 & 764,06 & $(1)(3)(4)$ \\
\hline (3) 8-12 Grades & 657 & 479,76 & $(1)(2)(4)$ \\
\hline (4) $>12$ Grades & 149 & 158.20 & $(1)(2)(3)$ \\
\hline Kruskal Wallis statistical test & 405.3339 \\
\hline \multicolumn{2}{|r|}{ Statistical significance } & $P=0.000001$ \\
\hline
\end{tabular}

Table 11

STATISTICAL SIGNIFICANCE OF OHI-S BY PARENTAL LEVEL OF EDUCATION 

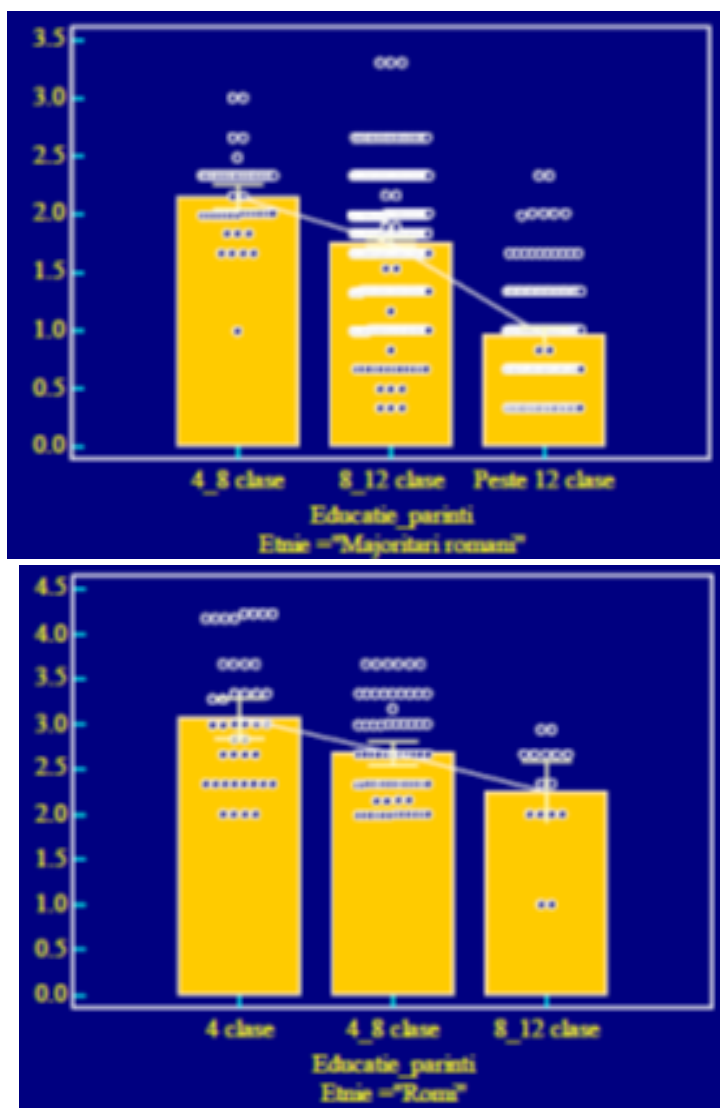

Fig. 6. OHI-S distribution by parental education category and ethnicity

The Roma subjects occupied higher percentages of the categories with high $\mathrm{OHI}$-S values. OHI-S values were higher in Roma subjects compared to Romanians.

In Romanian oral hygiene improves with age growth, the $\mathrm{OHI}-\mathrm{S}$ index decreases with increasing age. There are no statistically significant differences between age groups in Roma subjects.

A study applied to schoolchildren from rural areas in India, demonstrated that debris and calculus accumulation was lower among the higher grade (9-10) than lower grade (6-8) students [32]. A Greek study reported better oral hygiene status among 15-year old adolescents than younger ones [33].

$\mathrm{OHI}-\mathrm{S}$ decreases with the increasing level of education in both Romanians and Roma subjects. In every category of income, Romanians majority have been measured lower $\mathrm{OHI}-\mathrm{S}$ values than Roma minority.

The OHI-S index is higher in every category of income in Roma subjects, compared with Romanians, and the trend is to decrease the OHIS index with increasing income to both ethnicities. So, regardless of ethnicity, the state of oral hygiene is getting better with the increase in income. Higher income could provide better accessibility to paid medical services, access to better media information (TV, Internet), and the possibility to purchase the necessary hygiene products more easily.

Many studies have confirmed that there is connection between socioeconomic status and health, as well as a relationship between socio- economic status and the incidence and prevalence of caries. Therefore, a high caries risk is associated with socioeconomic factors, such as low quality of life, low educational level, and the impact of cultural life on the promotion of oral health. [30,34]

Other studies have determined a correlation between a high OHIS index and low socio-economic status. [35-36]

Studies conducted by WHO representatives in Eastern Romania concluded that the establishment of school- based oral health promotion programs in Romania is urgently needed [37].

In the last few years we have developed educational oral health programs in N-W Romania, focusing on determining of oral hygiene status, some of them on orthodontic patients, with the aim to raise awareness in schoolchildren on the importance of a proper oral hygiene. Self-checking with plaque disclosing solution may play a significant role in improving the oral hygiene of schoolchildren by improving brushing technique.

Results of our studies indicates a sole conclusion, namely that more and complex programs need to be implemented for improving oral health status of schoolchildren in these areas [3,38].

Implementation of prevention measures can stop the apparition of cavitary process and invasive and expensive treatments will be avoids [39].

\section{Conclusions}

The average value of the $\mathrm{OHI}-\mathrm{S}$ index in children in rural areas of $\mathrm{N}$-W Romania was 1.78, a higher value than most of the values identified in the bibliographical references.

The socio-economic status directly influences the values of the 0-HIS index, as the state of dental hygiene was improving with the increasing level of education and income.

Using disclosing agents may improve oral health status in schoolchildren, by increasing the awareness of their personal oral hygiene condition.

\section{References}

1.PETERSEN P., Global policy for improvement of oral health in the 21st century-implications to oral health research of World Health Assembly 2007, World Health Organization. Community Dent Oral Epidemiol, 37, no. 1, 2009, p.1-8.

2. ZAHRA S., Oral Health among Iranian Preadolescents: A SchoolBased Health Education, Helsinki 2010, Yliopistopaino, p.1-13.

3. VAIDA L., COREGA C., G. ROSEANU, Researches regarding current self-related cognitions in patients with orthodontic treatment. JCBPR, 9, no. 2, 2009, p.131.

4. LIN S., MAUK A., Addressing dental Diseases in rural India. Implementing public health interventions in developing countries. Int J Oral Health Sci, 2014, p.105.

5. LOCKER D., Deprivation and oral health: a review. Community Dent Oral Epidemiol, 28, 2000, p.161.

6 *** WHO information series on school health, Doc 11: Oral health promotion through schools, World Health Organization, Geneva, 2003. 7 MBWALLA H., J. MASALU, A. ASTROM, Socio-demographic and behavioural correlates of oral hygiene status and oral health related quality of life, the Limpopo - Arusha school health project (LASH): A cross-sectional study. BMC Pediatr., 2010, 10, p. 87.

8. ALMEIDA C., PETERSEN P., ANDRE S., TOSCANO A., Changing oral health status of 6- and 12-year-old schoolchildren in Portugal. Community Dent Health, 20, 2003, p. 211.

9. HOBDELL M., PETERSEN P, CLARKSON J., JOHNSON N., Global goals for oral health 2020., Int Dent J, 53, 2003, p.285.

10.FASOULAS A., PAVLIDOU E., MANTZOROU M., SEROGLOU K., GIAGINIS C., Detection of dental plaque with disclosing agents in the context of preventive oral hygiene training programs. Heliyon, 5, no. 7, 2019.

11.DATTA D., RAMESH KUMAR S., ASWATH NARAYANAN M.B., SELVAMARY A., SUJATHA A., Disclosing solutions used in dentistry. WJ PR, 6, no. 6, 2017, p. 1648.

12.ILICI R., MIHAI C., MIHAI L., SFEATCU R., Oral hygiene improvement by disclosing agents. Medical Connections, 2, no. 34, 2014.

13 NEPALE M., VARMA S., SURAGIMATH G., ABBAYYA K., ZOPE S., KALE V., A prospective case-control study to assess and compare the role of disclosing agent in improving the patient compliance in plaque control. J Oral Res Rev, 6, no. 2, 2014, p. 45. 
14 TEITELBAUM A., CZLUSNIAK G., Control of Dental Biofilm and Oral Health Maintenance in Patients with Down Syndrome. Subrata Kumar Dey, IntechOpen, 2013.

15.CHOUNCHAISITHI N., SANTIWONG B., ASVANIT P., Use of a Disclosed Plaque Visualization Technique Improved the SelfPerformed, Tooth Brushing Ability of Primary School children. J Med Assoc Thai, 97, no. 2, 2014, p.S88.

16..MONTEVECCHI M., CHECCHI V., GATTO M., KLEIN S., CHECCHI L., The Use of a Disclosing Agent During Resective Periodontal Surgery for Improved Removal of Biofilm. The Open Dentistry Journal, $\mathbf{6}$, 2012, p.46-50.

17. MEHTA A., KAUR G., Oral health-related knowledge, attitude, and practices among 12-year-old schoolchildren studying in rural areas of Panchkula, India. IJDR, 23, 2012, p. 293.

18. CHAUHAN D., Integration of Preventive and Promotive Oral Healthcare Practices Through School Health Systems- An unexplored Indian need. Report. Observer Research Foundation Mumbai, 2010. 19.LWANGA S., LEMESHOW S., WHO, Sample size determination in health studies: a practical manual, World Health Organization, Geneva, 1991.

20. *** WHO, Oral health surveys: basic methods. World Health Organization, Geneva, 1997.

21. VAIDA L., DIMA R., CUCE., NEGRUTIU B., MOCA A., ILIE I., DARAGIU D., ZALANA A., ALBERT E., TODOR B., Comparative Study on the Efficiency of Intermaxillary Elastic Polymers used in the Treatment of Skeletal Class II Malocclusions in Growing Patients. Mat. Plast, 56, no. 2, 2019, p. 341.

22. ROMANEC, C., DRAGOMIR, B., BICA,C., The Prophylactic Orthodontic Treatment with Removable Appliances in Children. Rev Chim. (Bucharest), 69, no. 3, 2018, p. 693.

23. VAIDA, L., MOLDOVAN, L., LILE, V, B. TODOR, A., PORUMB, I. TIG, D. BRATU, A comparative study on mechanical properties of some thermoplastic and thermo set resins used for orthodontic appliances. Mat. Plast, 52, no. 3, 2015, p. 364.

24. *** [Interactiv]. Available: http://www.mah.se/CAPP/Methods-andIndices / Oral-Hygiene-Indices / Simplified-Oral-Hygiene-Index-OHI$\mathrm{S}$.

25.***[Interactiv]. Available: https://en.wikipedia.org/wiki/ Brilliant Blue FCF.

26. NUAIMI M. A., FERGUSON D., AL-MULLA A., Oral hygiene status in school adolescents: a study of 20,000 school-age adolescents in 66 public and private schools comparing oral hygiene status by gender and ethnicity. Oral Health Dent Manag, 13, no. 2, 2014, p.474.

27. HOU R., MI Y., XU Q., WU F., MA Y., XUE P., XIAO G., ZHANG Y., WEI Y.,YANG W., Oral health survey and oral health questionnaire for high school students in Tibet, China. Head Face Med., 10, no. 1, 2014, p.17.
28. BERTAUD-GOUNOT V., KOVESS-MASFETY V., PERRUS C., TROHEL G., RICHARD F., Oral health status and treatment needs among psychiatric inpatients in Rennes, France: a cross-sectional study. BMC Psychiatry, 13, 2013, p. 227.

29. SUKHABOGI J., SHEKAR C., HAMEED I., RAMANA I., SANDHU G., Oral Health Status among 12- and 15-Year-Old Children from Government and Private Schools in Hyderabad, Andhra Pradesh, India. Ann Med Health Sci Res., 4, no. Suppl 3, 2014 p.S272.

30. SHABANI L., BEGZATI B., DRAGIDELLA F., HOXHA V., CAKOLLI V., BRUÇI B., The Correlation between DMFT and OHI-S Index among 10-15 Years Old Children in Kosova. Int J dent Oral Health, 5, 2015, p.2002.

31. ZUSMAN S., EATON K., HARRIS M., AMARIEI C., A pilot project to improve the oral health of orphans and of the elderly in residential care in Constanta, Romania. Community Dent Health, 32, no. 2, 2015, p. 89.

32. KUPPUSWAMY V., MURTHY S., SHARMA S., K. SURAPANENI, A. GROVER, A. JOSHI, Oral Hygiene Status, Knowledge, Perceptions and Practices among School Settings in rural South India. OHMD, 13, no. 1, 2014.

33. VADIAKAS G., OULIS C., TSINIDOU K., MAMAI-HOMATA E., POLYCHRONOPOULOU A., Oral Hygiene and periodontal status of 12 and 15-year-old Greek adolescents. A national Pathfinder survey. Eur Arch Paediatr Dent, 13, 2012, p. 11.

34. EBERHARDT M., PAMUK E., The Importance of Place of Residence: Examining Health in rural and nonrural areas. Amer J Public Health, 94, no. 10, 2004, p.1682

35. MBAWALLA H., MASALU J., ASTRØM A., Socio-demographic and behavioural correlates of oral hygiene status and oral health related quality of life, the Limpopo-Arusha school health project (LASH): a cross-sectional study. BMC Pediatr., 10, 2010, p. 87.

36. REHMAN M., MAHMOOD N., REHMAN B., The relationship of caries with oral hygiene status and extra-oral risk factors. J Ayub Med Coll Abbottabad, 20, no. 1, 2008, p. 103.

37. PETERSEN P., DANILA I., SAMOILA A., Oral health behavior, knowledge, and attitudes of children, mothers, and schoolteachers in Romania in 1993. Acta Odontologica Scandinavica, 53, no. 6, 1995, p. 363.

38. TODOR B., VAIDA L., SCROBOTA I., CIAVOI G., BERECHET D., MATEI R., LUCAN A., TODOR L., Evaluation of the Efficency of Dental Profilaxy Methods Applied to School Children from a Rural Disadvantaged Area. Medicine in Evolution, XXIII, 2017, p.181.

39. POP, A., CAMPIAN, R., JIMAN, P., IONESCU, E., MILICESCU, S., TEODORESCU, E., PACURAR, M., BECHIR, E., MOLA, F., TARMURE, $V$., Correlations Between pH Values of Oral Fluid and Dental Caries Epidemiologic Indicators in Children Aged within 6-12 Years. Rev Chim. (Bucharest), 69, no. 2, 2018, p.484.

Manuscript received: 6.01 .2019 